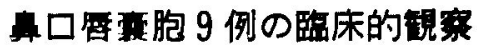

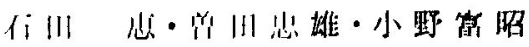

名合英明・伊滕秀夫

\section{Clinical observation on nine cases of nasolabial cyst}

\author{
Satoshi IsHIDA - Tadao SOdA - Toaki ONO \\ Hideaki Nagura - Hideo ITOH
}

\section{緒}

\section{曹}

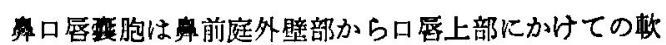

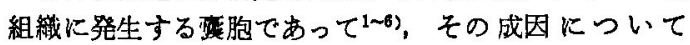
は久保7および Brown-Kelly らの貯溜胞説 ${ }^{8 \sim 12,28)}$ Brüggemann らの胎生器官残存説ならびに Blumenthal,

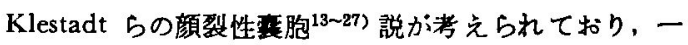
定していない．したがって 1893年の Zuckerkandl の最

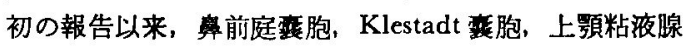

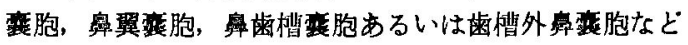
さまざまな名称で呼ばれていたが，1971年のWHO で

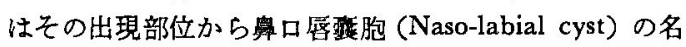

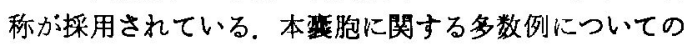

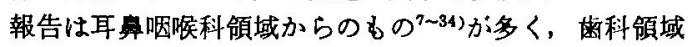
からの報告7,35 52) は1ないし2例の症例報告であるので, われわれは過去13年間に経験した 9 例について臨床的娭 討と文献的考察を試みた。

対 象

対象は1965年 1 月から1977年12月末までの13年間に当 科で経験した 9 例で（表 1 ），これは同期間の顔裂性 胞48例中の約19\%であった。

\section{結果ならびに考察}

\section{1. 患者の性および年齡}

患者の性別性男性 2 例，女性 7 例で， $1: 3.5$ の割合 で女性が多くなっていた，性別に関しては，Miller and More $^{31)}$ か 82 の文献例に自験の 3 例を加党た 85 例では，

東京医科菌科大学菌学部第 2 口腔外科学教室 （主任 : 伊藤秀夫教授）

The Second Department of Oral Surgery, Faculty of Dentistry Tokyo Medical and Dental University (Chief: Prof. Hideo Itoh)

受付日：昭和54年 7 月 26 日
男性はわずかに 3 例のみであったと報告しているが， Crawford ら 00 の94の文献例に自検例2例を加えた96例て は，男性20例，女性76例となっており，またRoed-Peter$\operatorname{sen}^{51)}$ の5例の自検例を加えた116例では，男性 (22\%), 女性90例 (78\%) で，女性は男性の約 3.5 倍となってお ク，われわれの経駗例の男女比とほほ同しでする。

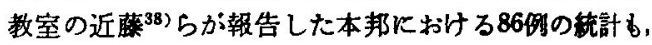
男性34例，女性52例で女性が多くなっている。

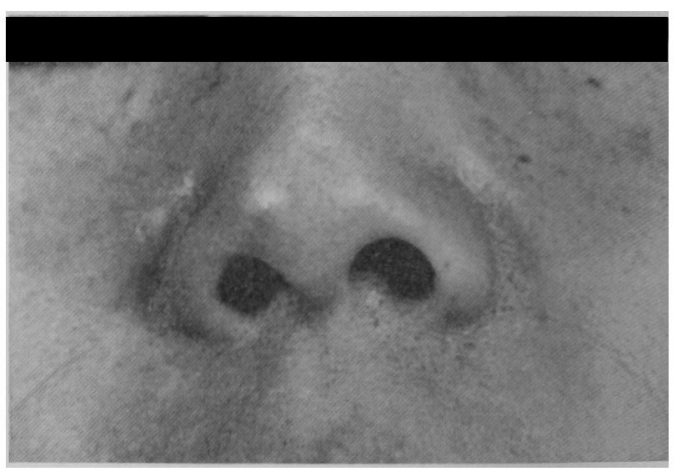

图 1 症例 7 の写真

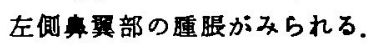

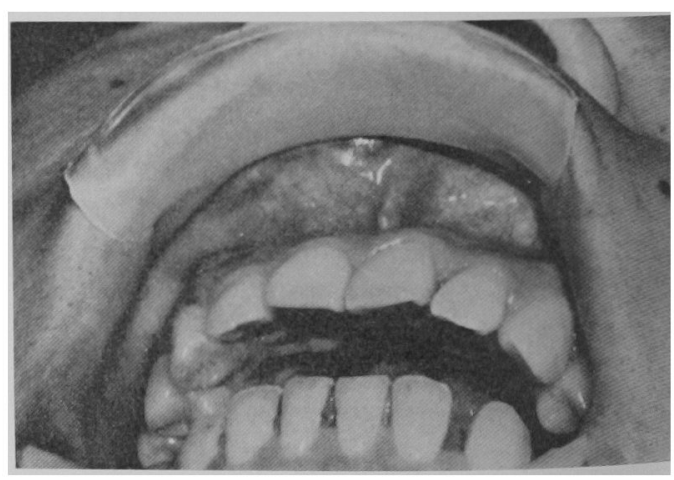

図 2 症例 6 の写真 1123 部の菌肉口唇移行部に聥脹がみられる。 


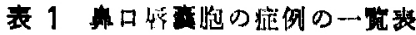

\begin{tabular}{|c|c|c|c|c|c|c|c|c|c|c|c|}
\hline \multirow[b]{2}{*}{ 症惻 } & \multirow[b]{2}{*}{ 性 } & \multirow[b]{2}{*}{ 年龄 } & \multirow[b]{2}{*}{ 部位 } & \multirow[b]{2}{*}{ 大きさ } & \multirow[b]{2}{*}{ 形 } & \multirow[b]{2}{*}{ 痛伐批間 } & \multicolumn{5}{|c|}{ I: 悠 症 汱 } \\
\hline & & & & & & & 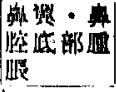 & 我 & 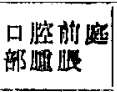 & 閉涊 & 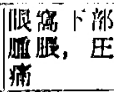 \\
\hline 1 & $q$ & 51 & 左 & 摭指顽大 & 円形 & 20年 & + & + & - & - & - \\
\hline 2 & $q$ & 66 & 右 & 拇指㳑大 & 円形 & 5 只月 & + & - & - & - & + \\
\hline 3 & $q$ & 31 & 左 & 小指频大 & 棈円形 & 1 年 & + & - & - & - & - \\
\hline 4 & $\delta$ & 23 & E & 小指頙大 & 円形 & 2 掘間 & + & - & + & - & - \\
\hline 5 & $q$ & 41 & 右 & 拇指嘼大 & 棈円形 & 13作 & + & - & - & - & - \\
\hline 6 & q & 33 & 左 & 拇指酸大 & 柿丹形 & 13か月 & + & - & + & + & - \\
\hline 7 & 9 & 45 & E & 小指顽大 & 棈円形 & 6加月 & + & - & + & - & - \\
\hline 8 & $q$ & 30 & 左 & 小指瞆大 & 円形 & 6か月 & + & - & - & - & - \\
\hline 9 & o & 40 & 右 & 拇指䫒大 & 円珍 & 10か月 & + & + & - & - & - \\
\hline 計 & 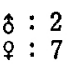 & $\begin{array}{l}\text { F均年龆 } \\
40 \text { 歳 }\end{array}$ & 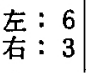 & 拇指頭大： 5 & $\begin{array}{ll}\text { 円形: } & 5 \\
\text { 楕円形 : } & 4\end{array}$ & & 9 & 2 & 2 & 1 & 1 \\
\hline
\end{tabular}

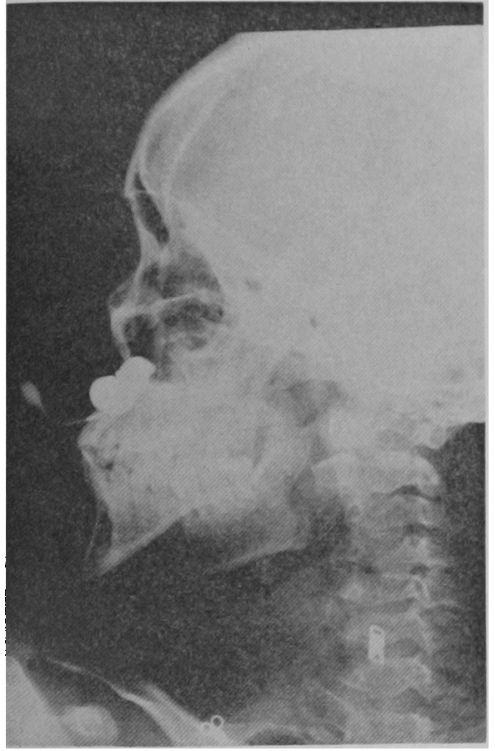

图 3 症例 6 の造影X線写真

患童の年龄は，最年少が23歳，最年長が66歳で，30歳 代と40歳代がそれぞれ3例ずつ，20嵗代，50歳代および 60瓷代が 1 例ずつであり，平均年㱓は40歳であった。

Roed-Petersen の報告では，10歳代 4.7\%，20歳代 17.0 $\%, 30$ 歳代 $26.4 \% ， 40$ 歳代 $22.6 \% ， 50$ 歳代 $14.2 \% ， 60$ 歳 代9.4\%，70歳代5.7\%で，30歳から49歳の間が多くなっ て出り，また近藤らの本邦の統計では，10歳代 7.0\%， 20 歳代 $38.4 \% ， 30$ 歳代 $26.7 \%$ ４0歳代 $17.4 \% ， 50$ 歳以上 10.5\%で，20歳代が最も多くなっている。.Waldrep ら ${ }^{49}$ の4加月の乳見に発見されたとの報告すあるが，一般に は欧米では Blumenthal の12歳が最年少，Kofler の75

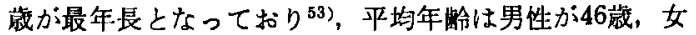

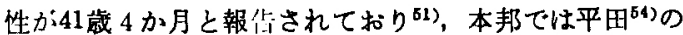
16藏の女性が最年少，下村 ${ }^{23)}$ の73藏が最年長のよらであ

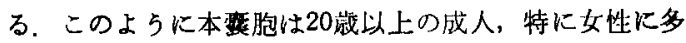
いのであるが，上皮芽や腺分泌が活発になる性的成熟 期，妊桭ないしは閉経などによる何らかの変調と関係が あるのではないかと考えられて特り，また外賃む誘因と して考えられている55

\section{2. 主要症状および病悩期間}

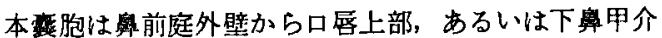
の側壁下部などの軟組織内に発生し，售胞が大きくなる と界翼基部から口唇上部にかけて隀脤が現れ，奥唇洗が 消失する。また奥腔底が隆起していわゆる Gerber の隆 起が現れ，さらには楀閉塞感もきたすことがあるといわ れている，口腔内では上口唇の内側面にる腫脹が現れ。 口腔前庭が浅くなることが多い，また 2 次感染によって 急性隀脹と疼痛，あるいは番腔底や口唇に瘦を形成する ことひある。われわれの 9 例の主要症状は奥翼部就よび 口唇上部の尰脹（図 1) は全例にみられたが，長清の 消失は2例のみであった，3例には口唇内側にも盾脹（図 2）がられそそのらちの1例は楀前庭の隆起も著明で 兽閉塞感を伴っていた，その他，眼窩下部の腫脹と自発 痛が1例ずつあったが，磨形成の症例はなかった。

本雍胞の発生は通常片側性で，われわれの 9 例む左側 6 例，右側 3 例であったか， 近藤らの統計では左側 30 例, 右側44例，正中部 5 例扎よび両側性 4 例であり， Roed-Petersen の116例では，102例は片側性で左右差は なく，両側性は13例（11.2\%）となっている.

症状に気ついてから来院するまでのいわゆる病脳期間 は一般に長く，Burtschi and Stout ${ }^{46)} の 37$ 年間という症 例むある. われわれの 9 例では 6 か月以内が 4 例， 1 年 


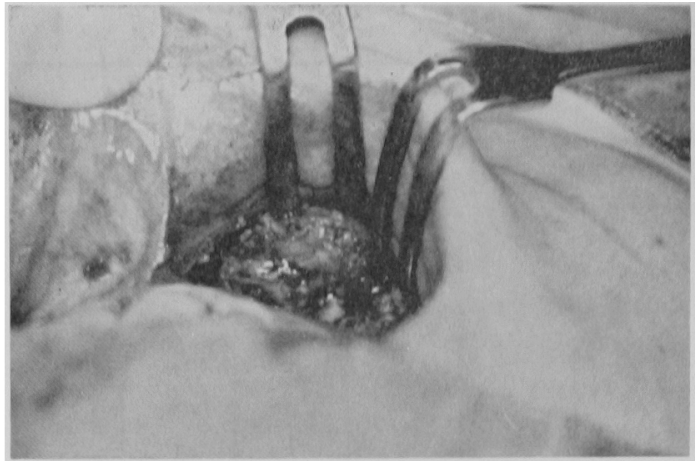

図 4 症例 7 の:梅所見

表 2 恶胞整の上皮

\begin{tabular}{|c|c|}
\hline & 上皮 圈 \\
\hline 多列円柱上皮 & 2 \\
\hline $\begin{array}{c}\text { 多列円柱上皮 } \\
\text { 十立方上皮 }\end{array}$ & 3 \\
\hline 杯勫胞 & 2 \\
\hline
\end{tabular}

以内が 2 例で, 計 6 例は 1 年以内に来院しており, 最短 は2 週間, 最長は20年であった。この病悩期間の長短に ついては翼胞の発育や感染および患者自身の認識の違い なよ゙に関係があるよらである。

\section{3. $\mathbf{x}$ 線所見および突胞の大きさ}

われわれは造影X線写真によって侻胸の大きさ，形括 よび周囲の骨との関係を観察した。整胞の大きさは小指 頭大 4 例, 拇指頭大 5 例で, 形は円形 5 例, 棈円形 4 例

（图3）であり，従来の報告と同様であった，骨表面に 栾胞の压迫所在部位に一致して, 上顎骨の前面に, 軽度

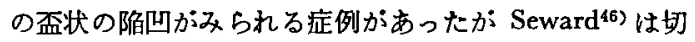
歯部の根尖部上方まで圧迫性の骨吸収像が文られる症例 があり，また骨の陷句が鼻切痕に及んでいる症例では， 梨状孔下縁の非対称性がみられる ${ }^{33,34,52)}$ といわれてい Ђ.

\section{4. 内容液}

本紊胞の内容は淡黄色のわずかに混濁したやや粘䅕性 の液体であるが，感染を経過した症例では黄楬色，淡黄 褐色, 緑黄色, 赤褐色あるいは黒褐色などの色調を呈す るむのが多いといわれている，われわれが内容液を観察

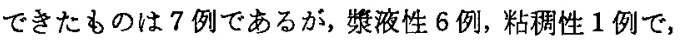
色調は淡黄褐色 4 例, 黒褐色 2 例および赤褐色 1 例で, いずれす多少混濁していた。 内容液の混濁は剝離上皮細 胞，多核白血球，赤血球などによるといわれているが， この点についての検索は行わなかった，内容液中にコレ ステリン結晶を含む症例む報告27されているが，われわ れにはそのよ5な症例はなかった．また，内容液の生化 学的分析に関する報告 $22,39 \sim 412$ るられるが, 症例数が少

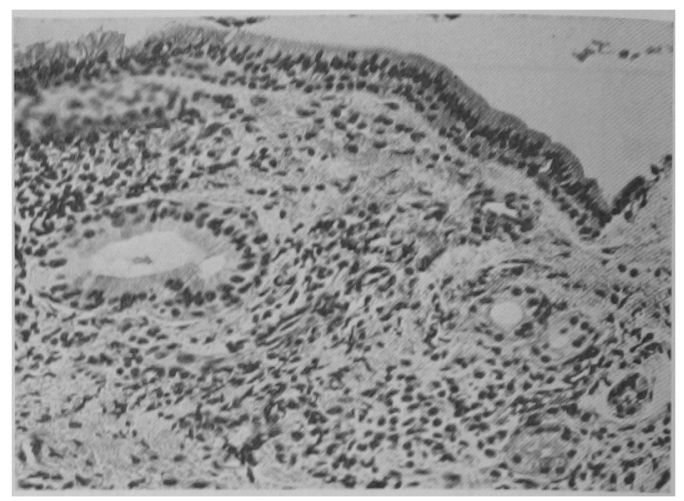

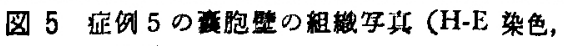
$\times 300$ )

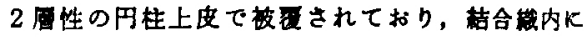
腺組維がみられる。

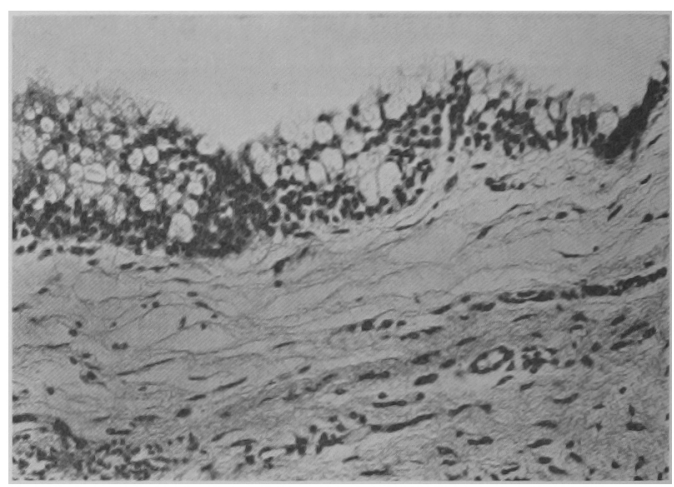

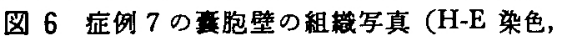
$\times 300$ )

多数の杯細胞がみられる。

なく，本咅胞を特徽づけるような結果は得られていない ようである。

\section{5. 治療と予後}

治㞠は口膑側から摘出するのが最良とされ，完全に摘 出されれば再発することはない，われわれの9例も全例 が口腔側より摘出された（图 4）が，手術所見で上顋骨

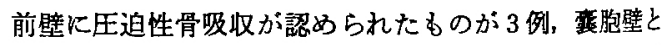
鼻腔底粘膜との瘾着が 2 例で， 4 例は骨吸収がなく，周 囲組織からの㔀離も容易であった。

\section{6. 病理組和学的所見}

組㵶学的㭘索は 6 例に行われた，上皮の被覆は6 例中 5 例にみられ，1例には上皮がなく線維性結合織の被膜 であった．また結合織内には全例に中等度の炎症性綀胞 浸潤が双られた。上皮の種類は多列円柱上皮が2例，多 列円柱上皮と立方上皮の混在が 3 例であり（表 2）, 後 者の 1 例には一部に線毛上皮が認められた。腺組織は全 例に存在し（図 5)，2 例には上皮内に杯細胞（图6） 
がるれた。

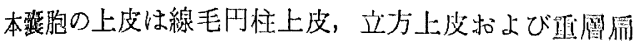
平上皮，あるいはこれらの混在といわれて扣り，近㾌ら の86例の統計では，円柱上皮（線毛上皮を含さ）47例， 立方上皮 7 例，重層唡平上皮 3 例拉よびこれらの混在 9 列となって扣り，Roed-Petersen の64例では，多列円柱: 上皮26例，多列円柱上皮之立方上皮の混在15例，多列円 柱上皮と重層扁平上皮の混在 9 例，立方上皮之重尿需平 上皮の混在 7 例，立方上皮 4 例灾よび 3 䅉の上皮の混在 が3例となっている，重䅉原平上皮は2次的な炎症性变化 による上皮の化生の結果とされているが，われわれの症 列煌重首平上皮はみられなかった.Roed-Petersen は 64例中22例に線毛上皮がみられたと報告して扣り，また Roed-Petersen は33例に, Shear は ${ }^{6)} 5$ 例中 4 例に杯細

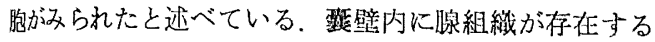
ことが多く，このことから，本等胞は Blumental 执よ び Klestadt らが述べているような顔裂性䖽胞に属する あのではなく，眝溜筑胞であると考える人が少なくな

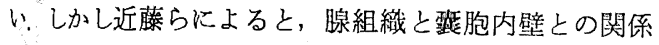
が確漶されたのは86例中 8 例のみであり，またShear も 同棣な所見は 5 例中 1 例のみと報告しているように，本 雚胞の成り立ちと裂壁内に存在する腺組織との関係につ いては、多数例による慎重な組織学的検索が必要である と思われる。

\section{結論}

1965年月 1 から1977年12月末までの13年間に経験した 鼻口唇率胞 9 例について検討して次の結果を得た。

1. 頻度は同期間に経験した顔裂性郦胞 48 例中約 $19 \%$ であった。

2. 性別は男 2 例, 女 7 例で, その比は $1: 3.5$ であっ た.

3. 年跉は30歳代拉よび40歳代がそれぞれ 3 例で多く, 最年少は23歳, 最年長は66歳で, 平均年龄は40歳であっ た。

4. 主要症状は全例が鼻翼部拈よび毁腔底の腫脹で, 3例には口腔側の腫脹がみられた。

5. 病脳期間は 6 例が 1 年以内で最も多く，最長は 20 年であった。

6. 蒥胞の大きさは小指頭大 4 例, 拇指頭大 5 例であ った.

7. 内容液は墏液性 6 例, 粘调性 1 例で, 色調は淡黄 褐色 4 例，黑褐色 2 例および赤褐色 1 例であった。

8. 全例が口腔側から摘出され，予後は良好であった。

9. 組織学的検索が行われた 6 例中 5 例に多列円柱上 皮なたは立方上皮による被覆がみられ，2 例には杯細胞 がみられた。 また全例に結合織内に腺組織が認められ た.

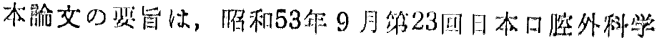

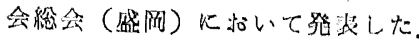

\section{引用文 献}

1) Gorlin, R.J.: Thoma's oral pathology. ed 7, Mosby Co, St Louis, 1974, p 458.

2) Shafer, W.G., et al.: A textbook of oral pathology.ed 3, W.B. Saunders Co, Philadelphia, 1974, p 71.

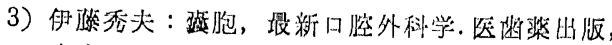
装宗，1975，40，593而。

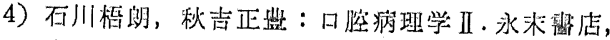
京都，1975，849買。

5) Killey, H.C., Kay, L.W.: Benign Cystic Lesion of the Jaws, their Diagnosis and Treatment. ed 3, E \& S. Livingstone, Ltd, Edinburgh \& London, 1977, p 114.

6) Shear, M.: Cysts of the Oral Resions. ed 1, John Wright \& Sons LTD, Bristol, 1976, p 86.

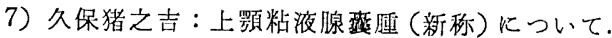
大日耳舆会報 26：262 1920 .

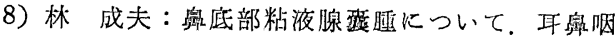
喉 6:921 1933.

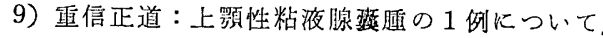
度応医学 14：1891934。

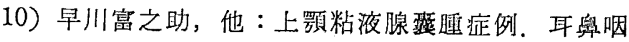
喉 24: 561952.

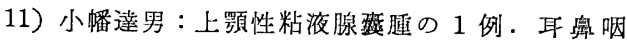
喉 25：379 1953.

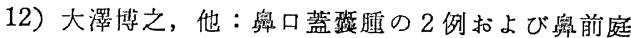
政嗹の 1 例。一特にその発生学的考察—. 耳學咽喉 47: 3511975.

13）石井 正：鼠前庭外側壁粘膜下に生ずる線毛円

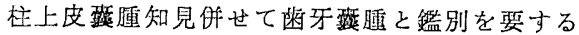

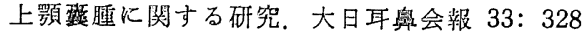
1927.

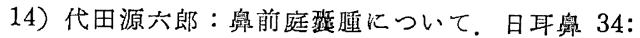
461928.

15）加藤二郎：本邦交献に表われたる上枵粘液蘶尰 (與前庭逰尰を含む)の統計的钼察。東医事新誌 2927: 10861935.

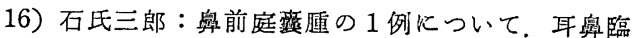
34: 4791939.

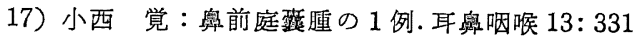
1940.

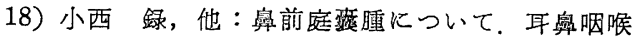
46: 10001940.

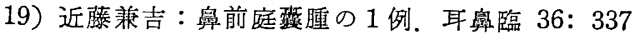
1941.

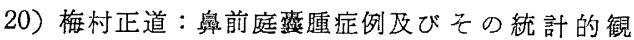
察，耳舆咽喉 22：301 1950.

21）石原 雄：奥前庭整腫 1 症例. 耳鼻咽喉 24: 216 1952. 


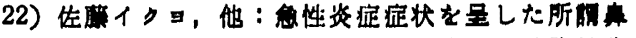

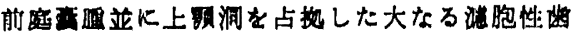

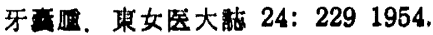

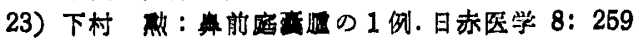
1955.

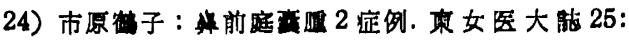
5771955.

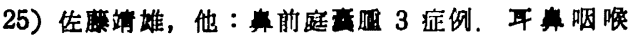
28: 5981956.

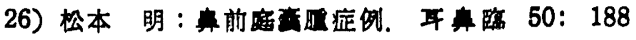
1957.

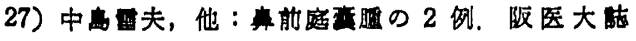
18: 1921958.

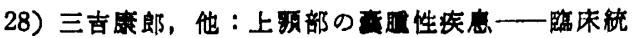

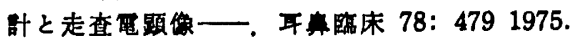

29) Arnoldi, W.: Uber die Genese der Nasenvorhofzysten. Laryngol Rhinol Otol 18: 581929.

30) Rosenberger, H.C.: Fissural cysts. Arch Otolaryngol 40: 2881944.

31) Miller, J.B. and Moore, P.M., Jr.: Nasoalveolar cysts. Ann Otol Rhinol Laryngol 58: 2001949.

32) Oppenheimer, P.: Nasoalveolar cyst. Arch Otolaryngol 74: 3421961.

33) Walsh-Waring, G.P.: Nasoalveolar cyst: aetiology, presentation and treatment six cases are reported. J Laryng Otol 81: 2631967.

34) Santora, E.Jr., et al.: Nasoalveolar cyst. report of case. J Oral Surg 28: 1171970.

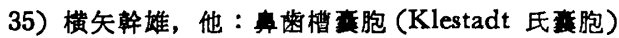
の 1 例. 日口外誌 6: 3301960.

36) 河合 幹, 他：㧘槽胞の 1 例. 日口外誌 7: 1021961.

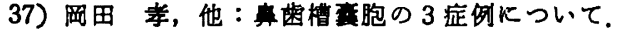
日口外誌 10：292 1964 .

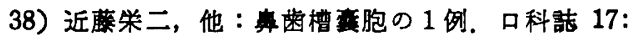

5941968.

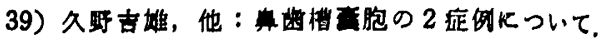
日口外誌 16:406 1970.

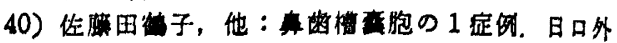
19: 1001973.

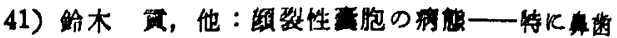

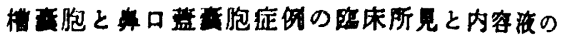
性状火ついて一。 日外䀩 20：29 1974.

42) Thoma, K.H.: Case reports. Naso-alveolar cyst. Am J Orthod 27: 481941.

43) Boone, C.G.: Nasoalveolar cyst. Oral Surg 8: 401955.

44) Atterbury, R.A.: Nasoalveolar cyst. Oral Surg 14: 7691961.

45) Rosen, M.D.: Naso-alveolar cyst. Report of case. Oral Surg 14: 1481961.

46) Seward, G.R.: Naso-labial cysts and their radiology. Dent Pract 12: 1541962.

47) Burtschi, T.A. and Stout, R.A.: Bilateral nasoalveolar cysts. Oral Surg 16: 2711963.

48) Rhymes, R.: Nasoalveolar cyst. report of case. J Oral Surg 21: 4351963.

49) Waldrep, A.C., Jr. and Capodanno, J.A.: Bilateral nasolabial cysts. report of case. J Oral Surg 24: 3471966.

50) Crawford, W.H., Jr.: Nasolabial cysts. report of two cases. J Oral Surg 26: 5821968.

51) Roed-Petersen, B.: Nasolabial cysts. A presentation of five patients with a review of the literature. Br J Oral Surg 7: 841969.

52) Brandao, G.S., et al.: Bilateral nasolabial cyst. Oral Surg 37: 4801974.

53) Blumenthal: 16) より引用.

54) 平田: 15) 上り引用.

55) Skupka, W.: 20)より引用。 